DE GRUYTER GOSPODARKA SUROWCAMI MINERALNYMI - MINERAL RESOURCES MANAGEMENT

\title{
Zeolite as a prospective material for the purification of automobile exhaust gases
}

\section{Introduction}

Currently, as our environment is loaded with various harmful substances originating from industrial activities and expanding car transportation, nature provides an excellent material that can cure the sore sites on our planet. This valuable material is natural zeolite known for its adsorption, ion-exchange and catalytic properties. By using suitable treatment one can obtain material with catalytic properties which can be used to reduce the amount of nitrogen oxides $\left(\mathrm{NO}_{\mathrm{x}}\right)$ produced during combustion processes.

Nitrogen oxides $\mathrm{NO}_{\mathrm{x}}\left(\mathrm{N}_{2} \mathrm{O}, \mathrm{NO}, \mathrm{NO}_{2}\right)$ are among the most frequently monitored components of the atmosphere. One cannot neglect the constantly increasing release of $\mathrm{NO}_{\mathrm{x}}$ to air due to human activities. This mostly involves the burning of fossil fuels in furnaces and automobile engines. We constantly record the exceeding of emission limits, particularly in town agglomerations.

* Ph.D., Associate Professor, University of Ss. Cyril and Methodius in Trnava, Faculty of Social Sciences, Slovakia.

** Ph.D., *** Professor, The Technical University of Košice, Faculty of Manufacturing Technologies with the seat in Prešov, Slovakia. 


\section{The influence of nitrogen oxides on the environment and human health}

The adverse influence of nitrogen oxides on the environment results in damage to the ozone layer and contribution to the greenhouse effect (Flimel 2008). The long-term effects of higher concentrations of nitrogen oxides decrease the resistance of organisms to infections and together with sulphur dioxide contribute to the development of chronic inflammatory diseases of the respiratory tract. Similar to carbon oxide, nitrogen oxide has higher affinity for hemoglobin than oxygen. The mentioned gases can also bind to hem groups in cytochromes and these effects are essential for their high toxicity. Dinitrogen oxide $\left(\mathrm{N}_{2} \mathrm{O}\right)$ is one of the substances which contribute to the greenhouse effect and damage the ozone layer. It passes from the troposphere to the stratosphere where it reacts with oxygen atoms to create nitrogen dioxide $\left(\mathrm{NO}_{2}\right)$ (Horbaj 1997).

$$
\begin{gathered}
\mathrm{N}_{2} \mathrm{O}+\mathrm{O} \rightarrow 2 \mathrm{NO} \\
\mathrm{NO}+\mathrm{O}_{3} \rightarrow \mathrm{NO}_{2}+\mathrm{O}_{2}
\end{gathered}
$$

In the atmosphere, under normal condition, an intensive turbulent mixing of exhaust gasses occurs and the decisive process is oxidation of $\mathrm{NO}$ by ozone. Such a reaction occurs mainly in industrial areas and places with a high concentration of transport vehicles.

\section{Reduction of nitrogen oxides emission based on the use of zeolites}

In September 2014, a new emission standard EURO 6 came into force, which placed stricter requirements on the emission of nitrogen oxides by Diesel engines. The substantial change in the standard in comparison with EURO 5 involves the reduction of the maximum allowed concentration of $\mathrm{NO}_{\mathrm{x}}$ from $0.18 \mathrm{~g} \cdot \mathrm{km}^{-1}$ to $0.08 \mathrm{~g} \cdot \mathrm{km}^{-1}$ and of $\mathrm{CH}+\mathrm{NO}_{\mathrm{x}}$ from $0.23 \mathrm{~g} \cdot \mathrm{km}^{-1}$ to $0.17 \mathrm{~g} \cdot \mathrm{km}^{-1}$. Table 1 summarizes development of EURO standards (Moravčík 2013).

To decrease nitrogen oxides, apart from conventional catalyzers one can also use synthetic and natural zeolites. Their use is based on several patents. One of them is an American patent US006029441A. This patent protects a device capable of decreasing the content of nitrogen oxides and hydrocarbons by means of zeolite. It consists of an adsorbent and two catalyzers. The catalyzer combined with an adsorbent comprises a monolithic carrier made from ceramic material such as cordierite, mullite or similar, or from metal material produced from thermally resistant steel (e.g. Fe-Cr-Al alloy) and a coat containing in its structure a metal material deposited by powder metallurgy. The pore density of this monolithic carrier ranges between 0.9 and 233 pores $/ \mathrm{cm}^{2}$. The adsorbent-catalyzer contains one of the noble metals group. This can involve $\mathrm{Pt}, \mathrm{Pd}$ and $\mathrm{Rh}$, which play a role in conversion of pollutants 
Table 1. Review of EURO standards

Tabela 1. Przegląd norm EURO

\begin{tabular}{|c|c|c|c|c|c|c|c|c|c|}
\hline \multirow{2}{*}{ Standard } & \multirow{2}{*}{ Year } & \multicolumn{2}{|c|}{$\begin{array}{c}\mathrm{CO} \\
{\left[\mathrm{g} \cdot \mathrm{km}^{-1}\right]}\end{array}$} & \multicolumn{2}{c|}{$\begin{array}{c}\mathrm{NO}_{\mathrm{x}} \\
{\left[\mathrm{g} \cdot \mathrm{km}^{-1}\right]}\end{array}$} & \multicolumn{2}{c|}{$\begin{array}{c}\mathrm{CH}+\mathrm{NO}_{\mathrm{x}} \\
{\left[\mathrm{g} \cdot \mathrm{km}^{-1}\right]}\end{array}$} & $\begin{array}{c}\mathrm{CH} \\
{\left[\mathrm{g} \cdot \mathrm{km}^{-1}\right]}\end{array}$ & $\begin{array}{c}\mathrm{DPF} \\
{\left[\mathrm{g} \cdot \mathrm{km}^{-1}\right]}\end{array}$ \\
\cline { 3 - 11 } & & gasoline & diesel & gasoline & diesel & gasoline & diesel & gasoline & diesel \\
\hline EURO 1 & 1992 & 3.160 & 3.160 & - & - & 1.130 & 1.130 & & \\
\hline EURO 2 & 1996 & 2.200 & 1.000 & - & - & 0.500 & 0.700 & & 0.080 \\
\hline EURO 3 & 2000 & 2.300 & 0.640 & 0.150 & 0.500 & - & 0.560 & 0.200 & 0.050 \\
\hline EURO 4 & 2005 & 1.000 & 0.500 & 0.080 & 0.250 & - & 0.300 & 0.100 & 0.025 \\
\hline EURO 5 & 2009 & 1.000 & 0.500 & 0.060 & 0.180 & - & 0.230 & 0.100 & 0.005 \\
\hline EURO 6 & 2014 & 1.000 & 0.500 & 0.060 & 0.080 & - & 0.170 & 0.100 & 0.005 \\
\hline
\end{tabular}

such as $\mathrm{NO}_{\mathrm{x}}, \mathrm{CO}$ and hydrocarbons. Noble metals can also be used in the form of oxides or supported by thermally resistant oxides, such as $\mathrm{Al}_{2} \mathrm{O}_{3}, \mathrm{SiO}_{2}, \mathrm{TiO}_{2}$ and $\mathrm{ZrO}_{2}$. Rhodium is effective in reducing nitrogen oxides and therefore is used in both the oxidation-reduction catalyzer and adsorption-catalytic device. Natural or synthetic zeolites known for their high thermal resistance are used as an adsorbent in this device. Examples of such zeolites are ZSM-5, USY and $\beta$ zeolite. A combination of two or several types of zeolites can be used. The pores in ZSM- 5 are relatively small, not exceeding $0.55 \mathrm{~nm}$, which is advantageous for the adsorption of small molecules. Although only zeolite itself can be used for adsorption, it is advisable to combine it with a noble metal, such as platinum, palladium or rhodium. The presence of the noble metal in the zeolite structure enables its regeneration without reducing its adsorption properties (Zheng et al. 2004). Of the available noble metals, palladium is favored due to its moderate price and facilitation of most effective regeneration of zeolite. The noble metal is incorporated in the structure of zeolite through ion exchange. The thermal stability of zeolite is preserved during the process. The noble-metal-enriched zeolite is not only capable of regeneration but exhibits also catalytic activity (Anunziata 2004). The adsorption of nitrogen compounds from exhaust gases of diesel motors on natural zeolite clinoptilolite was compared with the adsorption properties of synthetic zeolites $\mathrm{Na}-\mathrm{X}$ and $\mathrm{Na}-\mathrm{P}_{1}$ (Bandura et al. 2012). Studies investigating the adsorption of ammonium ions from water on clinoptilolite and synthetic zeolites of type Na-X were also carried out (Franus et. al. 2015).

As minerals found in cavities of volcanic rocks, zeolites have been known for more than 200 years. They were, however, considered more or less a mineralogical rarity without practical importance. Only after the introduction of modern identification mineralogic methods, such as X-ray diffraction analysis and scanning microscopy, it the determination of the crystallographic arrangement of zeolites was possible (Panda et al. 2011). The basic units of the hydrated aluminum silicate structure of zeolite minerals are $\left(\mathrm{SiO}_{4}\right)^{-4}$ and $\left(\mathrm{AlO}_{4}\right)^{-5}$ 
tetraheders linked together by oxygen atoms. This gives rise to cavities in their crystalline structure interconnected with channels containing alkali metal and alkaline earth metal cations surrounded with molecules of water. These water molecules are bound only by van der Waals forces and can be removed by heating (Melenová et al. 2003). The cations present in the channels can be replaced by other cations. After appropriate chemical treatment, zeolites exhibit not only adsorption but also catalytic properties (Barloková and Ilavský 2014). According to published literature, several base metal catalysts for effective $\mathrm{NO}_{\mathrm{x}}$ reduction exist. Studies have suggested that in the absence of the $\mathrm{NO}_{\mathrm{x}}$ inhibitors, such as $\mathrm{H}_{2} \mathrm{O}, \mathrm{CO}_{2}$, and $\mathrm{SO}_{2}$, in diesel exhaust, the addition of first row-transition metals to zeolite-supported catalysts results in a significantly improved reduction rate of $\mathrm{NO}_{\mathrm{x}}$. Among these supports, $\mathrm{Cu}-\mathrm{ZSM}-5$, a copper-exchanged zeolite catalyst, is used as a benchmark for hydrocarbon selective catalytic $\mathrm{NO}_{\mathrm{x}}$ reduction. Numerous studies have been conducted on the exchange of one metal ion with zeolites (Wusirika et al. 2005).

The available literature provides kinetic diameters of some molecules found in exhaust gases (Table 2) (Čejka and Žilková 2000; Sopková 1986).

Table 2. Kinetic diameters of molecules

Tabela 2. Kinetyczne średnice cząsteczek

\begin{tabular}{|c|c|}
\hline Molecule & Kinetic diameter $[\mathrm{nm}]$ \\
\hline $\mathrm{CO}$ & 0.376 \\
\hline $\mathrm{N}_{2}$ & 0.364 \\
\hline $\mathrm{NO}$ & 0.317 \\
\hline $\mathrm{O}_{2}$ & 0.346 \\
\hline $\mathrm{N}_{2} \mathrm{O}$ & 0.33 \\
\hline $\mathrm{H}_{2} \mathrm{O}$ & 0.265 \\
\hline $\mathrm{SO}_{2}$ & 0.36 \\
\hline $\mathrm{CO}_{2}$ & 0.33 \\
\hline $\mathrm{NH}_{3}$ & 0.36 \\
\hline $\mathrm{CH}_{4}$ & 0.4 \\
\hline
\end{tabular}

Large deposits of natural zeolites, namely clinoptilolite are located in the eastern part of Slovakia (Fig. 1). It is a potassium-calcium type of zeolite with a small proportion of iron, magnesium and sodium ions, with pores of approximately $0.4 \mathrm{~nm}$ in diameter. Raw zeolites are particularly well suited for trace-gas removal (Ackley 2003; Bandura 2015).

The aim of the study was to investigate the potential use of natural zeolite clinoptilolite and its modified forms as filters for decreasing the concentration of nitrogen oxide in automobile exhaust gases. 


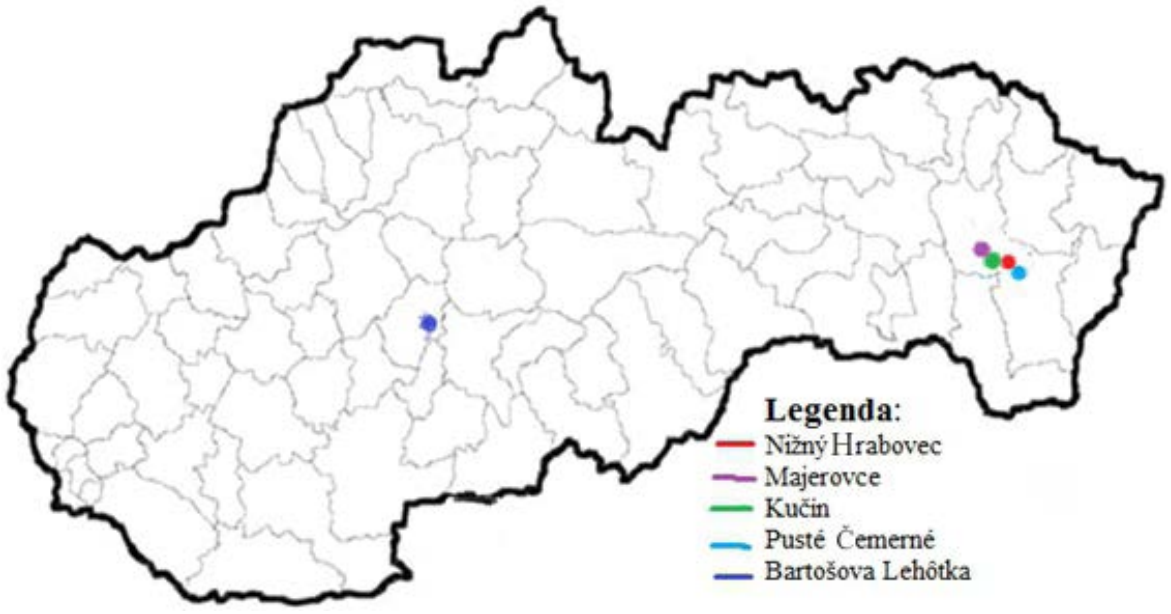

Fig. 1. Zeolite deposits in Slovakia

Rys. 1. Złoża zeolitu na Słowacji

\section{Material and methods}

Natural zeolite clinoptilolite was subjected to experimental measurements regarding the adsorption of nitrogen oxide by this natural material and the catalytic effectiveness of modified clinoptilolite. The investigated zeolite (grain size 5-8 $\mathrm{mm}$ ) originated from a deposit in Nižný Hrabovec, Slovakia. ZEOCEM, which exploits and processes this mineral, specifies also its chemical composition (Table 3 ).

Table 3. Chemical composition of zeolite from Nižný Hrabovec (ZEOCEM 2013)

Tabela 3. Skład chemiczny zeolitu z Nižný Hrabovec (ZEOCEM 2013)

\begin{tabular}{|c|c|c|c|}
\hline Chemical compound & Content [\%] & Chemical compound & Content [\%] \\
\hline $\mathrm{SiO}_{2}$ & $65.0-71.3$ & $\mathrm{Fe}_{2} \mathrm{O}_{3}$ & $0.7-1.9$ \\
\hline $\mathrm{Al}_{2} \mathrm{O}_{3}$ & $11.5-13.1$ & $\mathrm{MgO}$ & $0.6-1.2$ \\
\hline $\mathrm{CaO}$ & $2.7-5.2$ & $\mathrm{Na}_{2} \mathrm{O}$ & $0.2-1.3$ \\
\hline $\mathrm{K}_{2} \mathrm{O}$ & $2.2-3.4$ & $\mathrm{TiO}_{2}$ & $0.1-0.3$ \\
\hline $\mathrm{P}_{2} \mathrm{O}_{5}$ & 0.02 & $\mathrm{Si} / \mathrm{Al}$ & $4.5-5.4$ \\
\hline
\end{tabular}

The active component of zeolite in the rock from the deposit in Nižný Hrabovec is mineral clinoptilolite with its mean content in the rock ranging between $52 \%$ and $86 \%$. The 
essential portion of the exploited mineral is clinoptilolite of potassium-calcium type but a compact portion of sodium-calcium type is also present. The composition of clinoptilolite is expressed by the formula: $\left(\mathrm{Ca}, \mathrm{K}_{2}, \mathrm{Na}_{2}, \mathrm{Mg}\right)_{4} \mathrm{Al}_{8} \mathrm{Si}_{40} \mathrm{O}_{96} \cdot 24 \mathrm{H}_{2} \mathrm{O}$.

The following forms were investigated:

Thermally activated natural zeolite - after washing with distilled water the material was heated to $270^{\circ} \mathrm{C}$ for 2 hours.

Ammonia form - after washing with distilled water and drying up at $270^{\circ} \mathrm{C}, 1 \mathrm{M} \mathrm{NH} \mathrm{Nl}_{4} \mathrm{Cl}$ solution was added and zeolite was exposed to this solution for 24 hours at occasional mixing. Then the ammonia form was dried at $270^{\circ} \mathrm{C}$ for 2 hours.

Cobalt form - after decantation with distilled water and drying up at $270^{\circ} \mathrm{C}, 0.5 \mathrm{M}$ $\mathrm{CoCl}_{2}$ solution was added and zeolite was exposed to this solution for 24 hours at occasional mixing. Then the obtained cobalt form was dried at $270^{\circ} \mathrm{C}$ for 2 hours, allowed to cool and used as filter packing. The filtering layer was $15 \mathrm{~cm}$ thick and contained $700 \mathrm{~g}$ of zeolite.

We observed a decrease in the concentration of nitrogen oxide in automobile exhaust gases in relation to time caused by heat treated zeolite and its ammonia and cobalt modifications. Measurements were carried out at $25^{\circ} \mathrm{C}$ by a Smart Loger analyzer.

\section{Discussion and conclusion}

The preliminary measurements were made with specimens of natural untreated zeolite clinoptilolite. This material caused a $19.7 \%$ decrease on average in the concentration of the investigated components in the exhaust gases. After these measurements, the samples of zeolite were washed with water and thermally activated at $270^{\circ} \mathrm{C}$. The measured values are presented in Tables 4 and 5 .

The mean effectiveness of the filtration-adsorption device based on thermally activated zeolite was $31 \%$. In this case, the highest effectiveness was reached between fifteen and thirty seconds of action when it reached $75 \%$ and afterwards began to decrease rapidly down to $32 \%$ after the lapse of 90 seconds.

The chemical treatment of zeolite clinoptilolite consisted in the exposure of samples of a grain size from 5 to $8 \mathrm{~mm}$ to an ammonium chloride solution of a $1 \mathrm{~mol} \cdot \mathrm{dm}^{-3}$ concentration for 24 hours at occasional mixing. Then the samples were dried at $270^{\circ} \mathrm{C}$, allowed to cool and were used as filter packing. The results obtained with samples subjected to the treatment described above are presented in Table 6.

Another manner of the treatment of clinoptilolite consisted in the preparation of its cobalt modification. Optimum concentration of a cobalt salt solution ranges from 0.1 to $1 \mathrm{~mol} \cdot \mathrm{dm}^{-3}$. In our study we used a $0.5 \mathrm{~mol} \cdot \mathrm{dm}^{-3} \mathrm{CoCl}_{2}$ solution. A sample weighing $700 \mathrm{~g}$, of a grain size from 5 to $8 \mathrm{~mm}$ was first washed with distilled water and then dried at $270^{\circ} \mathrm{C}$. After drying, the sample was converted to ammonium form by exposure to $1 \mathrm{~mol} \cdot \mathrm{dm}^{-3}$ for 24 hours and dried again at $270^{\circ} \mathrm{C}$. After cooling, the sample was exposed to $0.5 \mathrm{~mol} \cdot \mathrm{dm}^{-3}$ $\mathrm{CoCl}_{2}$ solution for 5 hours at laboratory temperature. During this treatment, the originally 
Table 4. Results of measurements of NO in exhaust gases without filter and after the filter based on untreated natural clinoptilolite of a grain size from 5 to $8 \mathrm{~mm}$

Tabela 4. Wyniki pomiarów NO w gazach wylotowych bez filtru i z filtrem na bazie klinoptylolitu naturalnego niemodyfikowanego o wielkości ziarn od 5 do $8 \mathrm{~mm}$

\begin{tabular}{|c|c|c|}
\hline Time t $[\mathrm{s}]$ & $\begin{array}{c}\mathrm{NO}_{\mathrm{x}} \text { concentration without filter } \\
{\left[\mathrm{mg} \cdot \mathrm{m}^{-3}\right]}\end{array}$ & $\begin{array}{c}\mathrm{NO}_{\mathrm{x}} \text { concentration after filter } \\
{\left[\mathrm{mg} \cdot \mathrm{m}^{-3}\right]}\end{array}$ \\
\hline 0 & 0 & 0 \\
\hline 15 & 7.0 & 17.0 \\
\hline 30 & 19.0 & 23.1 \\
\hline 45 & 35.2 & 33.2 \\
\hline 60 & 50.2 & 51.7 \\
\hline 90 & 68.6 & 61.5 \\
\hline 120 & 81.4 & 71.24 \\
\hline 150 & 98.2 & 83.7 \\
\hline 180 & 101.5 & 81.7 \\
\hline 210 & 101.8 & 81.7 \\
\hline 240 & 101.8 & 81.7 \\
\hline 270 & 101.8 & 81.7 \\
\hline 300 & 101.8 & 81.7 \\
\hline 330 & 101.8 & \\
\hline
\end{tabular}

Table 5. Results of measurements of NO in exhaust gases without filter and after the filter based on thermally activated clinoptilolite of a grain size 5 to $8 \mathrm{~mm}$

Tabela 5. Wyniki pomiarów NO w gazach wylotowych bez filtru i z filtrem na bazie klinoptylolitu aktywowanego termicznie o wielkości ziarn od 5 do $8 \mathrm{~mm}$

\begin{tabular}{|c|c|c|}
\hline Time $\mathrm{t}[\mathrm{s}]$ & $\begin{array}{c}\text { NO concentration without filter } \\
{\left[\mathrm{mg} \cdot \mathrm{m}^{-3}\right]}\end{array}$ & $\begin{array}{c}\text { NO concentration after filter } \\
{\left[\mathrm{mg}^{-3}\right]}\end{array}$ \\
\hline 0 & 1.34 & 0 \\
\hline 15 & 5.34 & 1.34 \\
\hline 30 & 19.0 & 18.36 \\
\hline 45 & 33.5 & 30.8 \\
\hline 60 & 45.5 & 45.0 \\
\hline 90 & 65.7 & 56.0 \\
\hline 120 & 80.4 & 56.28 \\
\hline 150 & 91.1 & 62.98 \\
\hline 180 & 96.5 & 68.3 \\
\hline 210 & 96.5 & 69.68 \\
\hline 240 & 96.5 & 72.36 \\
\hline 270 & 96.5 & 72.36 \\
\hline 300 & 96.5 & 72.36 \\
\hline 330 & 96.5 & \\
\hline
\end{tabular}


Table 6. Results of measurement of NO in exhaust gases without filter and after the filter based on ammonium form of clinoptilolite of a grain size from 5 to $8 \mathrm{~mm}$

Tabela 6. Wyniki pomiaru NO w gazach wylotowych bez filtra, jak i po filtrze, na bazie klinoptylolitu modyfikowanego amoniakiem o wielkości ziarna od 5 do $8 \mathrm{~mm}$

\begin{tabular}{|c|c|c|}
\hline Time $\mathrm{t}[\mathrm{s}]$ & $\begin{array}{c}\text { NO concentration without filter } \\
{\left[\mathrm{mg} \cdot \mathrm{m}^{-3}\right]}\end{array}$ & $\begin{array}{c}\text { NO concentration after filter } \\
{\left[\mathrm{mg} \cdot \mathrm{m}^{-3}\right]}\end{array}$ \\
\hline 0 & 0 & 0 \\
\hline 15 & 10.3 & 8.1 \\
\hline 30 & 22.3 & 16.12 \\
\hline 45 & 34.5 & 11.3 \\
\hline 60 & 49.27 & 15.5 \\
\hline 90 & 75.6 & 27.0 \\
\hline 120 & 95.1 & 35.8 \\
\hline 150 & 106.0 & 43.2 \\
\hline 180 & 109.3 & 44.5 \\
\hline 210 & 115.7 & 52.5 \\
\hline 240 & 116.1 & 50.6 \\
\hline 270 & 116.1 & 50.6 \\
\hline 300 & 116.1 & 50.6 \\
\hline 330 & 116.1 & 50.6 \\
\hline 360 & 116.1 & 50.6 \\
\hline 390 & 116.1 & 50.6 \\
\hline 420 & 1161 & 50.6 \\
\hline
\end{tabular}

green coloring of clinoptilolite changed to blue. This was probably the result of the development of an ammonium complex $\left[\mathrm{Co}\left(\mathrm{NH}_{3}\right)_{4}\right]^{2+}$. Clinoptilolite treated in this manner was dried and used as automobile exhaust gases filter packing. The decrease in concentration of NO in exhaust gases when using this filter in relation to the time of action is presented in Table 7.

The Co-modified clinoptilolite decreased the content of nitrogen oxide within the initial seconds by $41.8 \mathrm{mg} \cdot \mathrm{m}^{-3}$. After 270 seconds, after the material heated up, we could also observe the catalytic effect of cobalt ions incorporated in the structure of clinoptilolite and the concentration of nitrogen oxide stabilized at the level of $22.75 \mathrm{mg} \cdot \mathrm{m}^{-3}$.

The measured values were used to calculate the effectiveness of the filter based on various types of clinoptilolite samples by means of the following formula:

$$
\text { Effectiveness }[\%]=\left[\left(\mathrm{c}_{1}-\mathrm{c}_{2}\right) / \mathrm{c}_{1}\right] \cdot 100
$$

The calculated effectiveness is presented in Table 8 . 
Table 7. Decrease in concentration of NO by cobalt modification of clinoptilolite

Tabela 7. Zmniejszanie stężenia NO po zastosowaniu klinoptylolitu modyfikowanego kobaltem

\begin{tabular}{|c|c|}
\hline Time $\mathrm{t}[\mathrm{s}]$ & Concentration of NO $\left[\mathrm{mg} \cdot \mathrm{m}^{-3}\right]$ \\
\hline 30 & 41.48 \\
\hline 60 & 40.14 \\
\hline 90 & 38.80 \\
\hline 120 & 32.11 \\
\hline 150 & 28.10 \\
\hline 180 & 25.42 \\
\hline 210 & 24.09 \\
\hline 240 & 24.09 \\
\hline 270 & 22.75 \\
\hline 300 & 22.75 \\
\hline 330 & 22.75 \\
\hline 360 & 22.75 \\
\hline 390 & 22.75 \\
\hline 420 & 22.75 \\
\hline 450 & 22.75 \\
\hline 510 & 22.75 \\
\hline 600 & 22.75 \\
\hline
\end{tabular}

Table 8. Mean effectiveness of a filter containing natural and treated forms of zeolite

Tabela 8. Średnie skuteczności filtra zawierającego naturalne i modyfikowane formy zeolitu

\begin{tabular}{|l|c|}
\hline Zeolite modification & Effectiveness of zeolite filter [\%] \\
\hline Natural zeolite & 19.7 \\
\hline Thermally treated & 31 \\
\hline Ammonium form & 59 \\
\hline Cobalt form & 46.4 \\
\hline
\end{tabular}

Figures 2 and 3 illustrate changes in effectiveness of clinoptilolite in relation to time in its natural form and form modified by ammonium chloride.

Since the 1950s, in relation to the release of many harmful substances into air and water by developing industry and more intensive transportation, increased efforts were taken to use zeolites for the treatment of these environmental components in order to decrease the load of pollutants on the environment. 


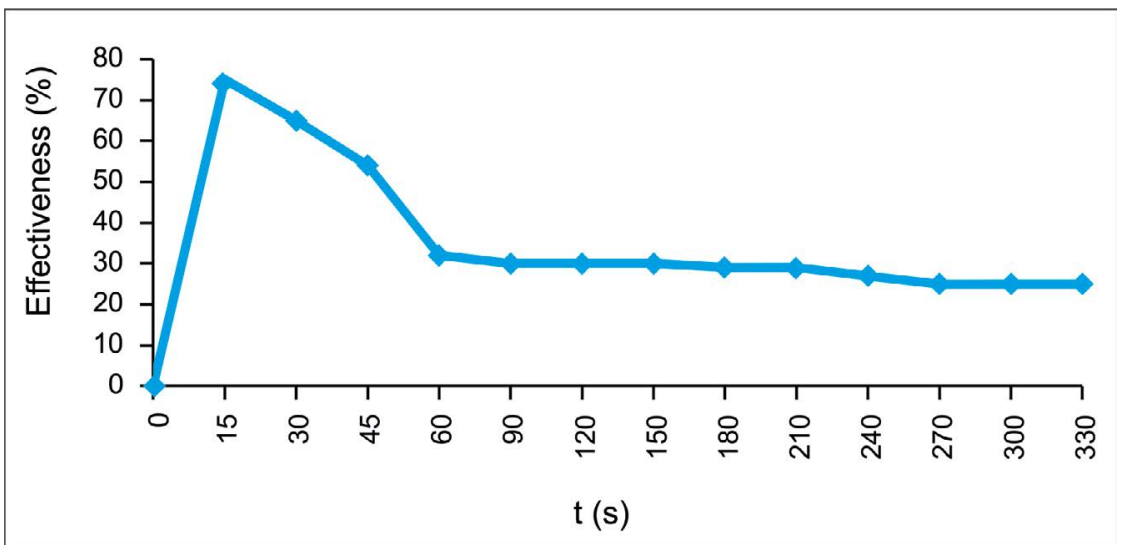

Fig. 2. Time related changes in effectiveness of a filter based on thermally activated clinoptilolite Rys. 2. Zmiany w skuteczności filtra w czasie na bazie klinoptylolitu aktywowanego termicznie

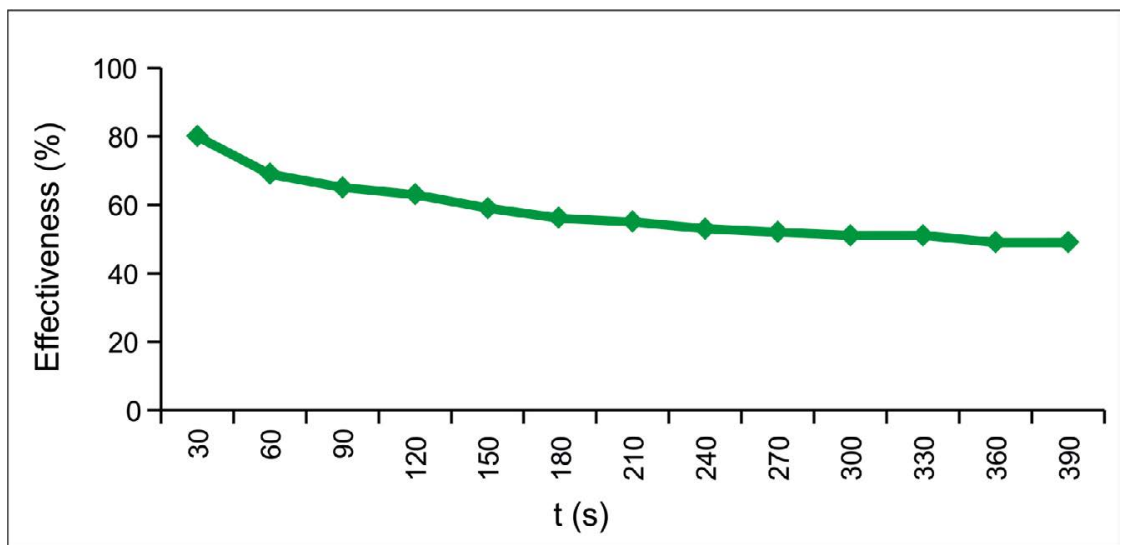

Fig. 3. Time related changes in effectiveness of a filter based on ammonium modification of clinoptilolite

Rys. 3. Zmiany w skuteczności filtra w czasie na bazie klinoptylolitu modyfikowanego amoniakiem

Emissions of nitrogen oxides have been the subject of considerable concern mainly due to their potential influence on human health, negative effect on the stratospheric ozone and contribution to the greenhouse effect. Thus, it appears necessary to decrease the emissions of nitrogen oxides to the lowest possible level. Apart from conventional catalyzers one can also use synthetic and natural zeolites for this purpose. Their application has been based on several patents, many of them using synthetic zeolites.

With respect to price it appears advantageous to replace synthetic zeolites with their natural form which, after appropriate chemical treatment, exhibit better adsorption properties 
and also acquire catalytic properties. Such treatment is relatively simple and inexpensive. Our study showed the very good effectiveness of the cobalt modification of natural zeolite which exhibited not only adsorption but also catalytic properties. After initial stabilization, its effectiveness did not change with time. An important aspect is that zeolites can decrease the concentration of nitrogen oxides in exhaust gases also during the cold start.

\section{REFERENCES}

Ackley, M. and Yang, R. 1991. Adsorption characteristics of High- Exchange clinoptilolites. Ind. Eng. Res. 30, pp. 2523-2530.

Ackley, et al. 2003. Application of Natural Zeolites in the Purification and Separation of Gases. Microporous and Mesoporous Materials 61(1-3), pp. 25-42.

Anunziata, O.A. 2004. Fe-containing ZSM-11 zeolites as active catalyst for SCR of $\mathrm{NO}_{\mathrm{x}}$ : part I. Synthesis, characterization by XRD, BET and FTIR and catalytic properties. Appl. Catal. A Gen. 264(1), pp. 93-101.

Bandura et al. 2015 - Bandura, L., Panek, R., Rotko, M. and Franus, W. 2015. Synthetic zeolites from flush for an effective tramping of BTX in the gas stream. Microporous and Mesoporous Materials 223, pp. 1-9.

Barloková, D. and Ilavský, J. 2014. Prírodné zeolity s vrstvou $\mathrm{MnO}_{2}$ na povrchu v úprave vody. Chem. Listy, No. 108, pp. 1153-1157.

Čejka, I. and Žilková, E. 2000. Syntéza a štruktúra zeolitov. Chemické listy 94, pp. 278-287 (in Czech).

Flimel, M. 2008. Work environment as a section of facility management. In: Annals of Faculty of Engineering Hunedoara Vol. 6, no. 3, pp. 104-109.

Franus et al. 2015 - Franus, M., Wdowin, M., Bandura, L. and Franus, W. Removal of environmental pollutions using zeolites from fly ash: a review. Fresenius Environmental Bulletin 24(2), pp. 854-866.

Horbaj, P. 1999. Ekologické aspekty spal'ovania. 22 s. Košice: TU (in Czech).

Melenová, L. et al. 2003. Odstraňování amoniaku z odpadních plynů adsorpcí na zeolitech a jejich následné využití v zemnědělství. Chem. Listy. No. 97, pp. 562-568.

Moravčík, L. 2013. Prichádza emisný predpis EURO VI. In: Sprievodca svetom dopravcu No. 11, pp. 5-11, United States Patent, US 006029441A, 29.02.2000 (in Czech).

Panda et al. 2011 - Panda, A., Duplák, J. and Jurko, J. 2011. Analytical expression of T-vc dependence in standard ISO 3685 for cutting ceramic. In: Key Engineering Materials Vol. 480-481, pp. 317-322.

Sopková, A. 1986. Molekulové zlúčeniny. Košice: UPJŠ. pp. 204-212 (in Czech).

Wdowin et al. 2015 - Wdowin, M., Macherzyński, M., Panek, R., Górecki, J. and Franus, W. 2015. Investigation of the sorption of mercury vapour from exhaust gas by an Ag-X zeolite. Clay Minerals 50 (1), pp. 31-40.

Zheng, G., Huang, W.H., and Lu X.H. 2004. Environmental Informatics Archives 2, 711 pp.

ZEOCEM, 2013. Minerals for Healthy Life, Zeolite - a Rare Gift of Nature. http://www.ZEOCEM.sk

Wan et al. 2006 - Wan, Y., Yang, H., Zhao, D. 2006. Host - Guest, Chemistry in the Synthesis of Ordered Non-siliceous Mesoporous Materials, Acc. Chem. Res. 39(7), pp. 423-432.

Wusirika et al. 2005 - Wusirika, R., Ogunwumi, S. and Lucas, W. 2005. Extruded Zeolite Catalysts for Lean Exhaust Application, Reprinted From: Advanced Catalysts and Substrates, SAE World Congress Detroit, Michigan April 11-14, 2005. 
ZEOLIT JAKO POTENCJALNY MATERIAL DO OCZYSZCZANIA SPALIN SAMOCHODOWYCH

Słowa kluczowe

tlenki azotu, zeolity, klinoptylolit, środowisko

\section{Streszczenie}

Badania przeprowadzono w celu zbadania skuteczności naturalnego zeolitu klinoptylolitu aktywowanego termicznie i w zmodyfikowanej formie do zmniejszania stężenia tlenków azotu w gazach spalinowych samochodów. Ponieważ tlenki azotu przyczyniają się do zwiększenia efektu cieplarnianego, społeczeństwo zwiększa presję na producentów samochodów do wzmożenia wysiłków w kierunku redukcji emisji gazów cieplarnianych. Jedną z możliwości jest stosowanie kombinacji konwencjonalnej trójdrogowego konwertora katalitycznego albo z syntetycznych lub naturalnych modyfikowanych zeolitów. Obecnie znane są nowe rozwiązania, które jednak chronione są patentami. W tym badaniu, naturalny zeolit klinoptylolit (wielkość ziarn 5-8 $\mathrm{mm}$ ) po obróbce cieplnej $\left(270^{\circ} \mathrm{C}, 2\right.$ godziny) i zmodyfikowaniu formy (amoniak, kobalt) użyto w postaci filtrów. Wyniki pomiarów wykazały wysoką skuteczność badanych form, które są stosunkowo łatwe do wytworzenia i są korzystne ekonomicznie w porównaniu z syntetycznymi alternatywami. Obróbka zeolitu ciepłem i amoniakiem zmniejszyła stężenia tlenków azotu w gazach odlotowych odpowiednio o 31 i 59\%. Zeolit modyfikowany kobaltem wykazywał nie tylko adsorpcję, ale również właściwości katalityczne, które są skuteczne w zmniejszaniu emisji tlenków azotu. Po wstępnej stabilizacji, jego skuteczność nie zmienia się w czasie. Dzięki tej modyfikacji, redukcja 46,4\% emisji tlenków azotu została osiągnięta.

\section{ZEOLITE AS A PROSPECTIVE MATERIAL FOR THE PURIFICATION OF AUTOMOBILE EXHAUST GASES}

\section{Keywords}

nitrogen oxides, zeolites, clinoptilolite, environment

\section{Abstract}

Examinations were carried out to investigate the effectiveness of natural zeolite clinoptilolite and its thermally activated and modified forms in decreasing the concentration of nitrogen oxides, the frequently monitored components of the environment, in automobile exhaust gases. Since nitrogen oxides contribute to the greenhouse effect, the public increases pressure on motor vehicle manufacturers to intensify their efforts toward the reduction of the relevant emissions. One option is the use of a combination of a conventional three-way catalytic converter with either a synthetic or modified natural zeolite. Researchers and designers are coming up with new solutions, which are protected by patents. In this study, natural zeolite clinoptilolite (grain size $5-8 \mathrm{~mm}$ ) and its thermally treated 
$\left(270^{\circ} \mathrm{C}, 2\right.$ hours) and modified forms (ammonia, cobalt) were used in the form of filters. The results of our measurements showed high the effectiveness of the tested forms which are relatively easy to prepare and are economically advantageous in comparison with the synthetic alternatives. The heat treated and ammonia forms decreased the concentration of nitrogen oxides in the exhaust gases by $31 \%$ and $59 \%$, respectively. The cobalt form appeared prospective as it exhibited not only adsorption but also catalytic properties which are effective in decreasing nitrogen oxides emissions. After initial stabilization, its effectiveness did not change with time. With this modification, $46.4 \%$ reduction in nitrogen oxide emissions was achieved. 
